\title{
The Effect of Organizational Culture and Information Asymmetry on Tendency of Accounting Fraud
}

\author{
Riri Pratiwi ${ }^{1}$, Hari Setiyawati ${ }^{2}$ \\ \{ririe.pratiwi99@yahoo.com ${ }^{1}$, hari_setiyawati@mercubuana.ac.id ${ }^{2}$ \} \\ Department of Accounting Universitas Mercu Buana, Jakarta, Indonesia ${ }^{12}$
}

\begin{abstract}
This study aims to examine the effect of organizational culture and information asymmetry to accounting fraud tendencies. The population of this research is Regional Work Unit (SKPD) South Tangerang and Tangerang City. The data sources used in this study is primary data. Primary data is obtained from the answer to the questionnaire in the respondent's content. The questionnaire was used to collect data and research samples of 40 respondents and research sample of 41 respondents. The sampling technique used was purposive sampling technique. The data obtained were analyzed using the PLS analysis technique (Partial Least Square) through the PLS software. The results showed that organizational culture had a significant effect on accounting fraud, while information asymmetry had no significant effect on accounting fraud.
\end{abstract}

Keywords: Organizational Culture, Information Asymmetry, Tendency of Accounting Fraud

\section{Introduction}

Accounting fraud has become a worldwide phenomenon and a major issue of concern. And so much news about the fraud that occurred in Indonesia including tax manipulation, banking case, manipulation case or misstatement of financial statements, and corruption case that occur in various ways. Some of fraud phenomena that occur in Indonesia are information from Badan Kepegawaian Negara - Indonesian National Civil Service Agency regarding corrupt civil servants at the central and regional levels. One of the cases of fraud that occurred in South Tangerang City Government was a budget misappropriation estimated to reach Rp 1,7 billion, which was found by BPK in FY 2017, which involved 5 units of Regional Work Unit (Satuan Kerja Perangkat Daerah/SKPD). And the case of fraud in Tangerang was the stipulation of Lurah Paninggilan as a suspect in illegal levies case in the implementation of Complete Systematic Land Registration (Pendaftaran Tanah Sistematis Lengkap/PTSL) program.

The tendency of accounting fraud is defined as any action, policies and measures, deception, concealment and improper disguise in presentation the financial statements and in managing the organizational assets that lead to the goal of achieving profit for itself and making others the injured party [1]. Fraud in accounting can occur because of three factors: pressure, opportunity, and rationalization. Pressure is where fraud is driven by an urgent need. Opportunity is a condition that allows someone to commit fraud. Factors that can affect the occurrence of these condition include information asymmetry. Rationalization is the existence of an attitude, character, or ethical values that allow someone to do dishonest actions or to be 
in an organizational environment or culture that gives them enough pressure to cause them justify such dishonest actions [2] [3] [4].

Studies that examine the factors that affect the tendency of accounting fraud have been carried out. However, previous studies have shown different results. The results of study conducted by Kiswanto et al., [5] showed that ethical culture of an organization had no effect on the tendency of accounting fraud. But the study conducted by Indriani [6] showed that culture of an organization had an effect on the tendency of accounting fraud. Study conducted by Wilopo [7] showed that there had been a positive relationship between information asymmetry towards the tendency of accounting fraud, and the study conducted by Widhiastuti et al., [8] showed that information asymmetry had no effect on the tendency of accounting fraud.

\subsection{Theoretical Review \\ 1.1.1 Fraud}

In accounting or auditing, fraud is interpreted as dishonest act and fraud can also be interpreted as deception. There are several definitions and understandings of fraud. One of them is the definition according to Kieso et al [9]"A fraud is a dishonest act by an employee that results in personal benefit to the employee at a cost to the employer". Whereas according to Arens et al [10]"Fraud is an intentional misstatement of financial statements". Accounting fraud according to the Institute of Indonesia Chartered Accountants (Ikatan Akuntan Indonesia) in Wilopo [7] is: 1) Misstatements arising from fraud in financial statements, namely misstatement or deliberate removal of amounts or disclosures in the financial statements to deceive the users of the financial statements. 2) Misstatements arising from improper treatment, this is often referred to as misuse or misappropriation relating to the theft of assets which results in financial statements not presented in accordance with generally accepted accounting principles in Indonesia. According to Tuanakotta in Purnomo [11] the causes of fraud or often referred to as fraud triangle are: 1) Pressure, 2) Opportunities and 3) Rationalization. The Association of Certified Fraud Examiners (ACFE) divides fraud into three major types or typologies based on actions, namely: 1) Asset Misappropriation, 2) Fraudulent Statement and 3) Corruption.

\subsubsection{Organizational culture}

According to Robins and Coulter [12] "Organizational culture has been described as the shared values, principles, traditions, and ways of doing things that influence the way organizational members act and that distinguish the organization from other organizations". According to Schein in Zheng et al., [13] organizational culture refers to shared assumptions, values, and norms. There are seven elements that describe the culture of an organization, according to Robins and Coulter [12]: 1) Innovation and Risk Taking. How much the organization encourages its employees to be innovative and dare to take risks. 2) Attention to Detail. How much accuracy, analysis, and attention to detail is demanded by the organization from its employees. 3) Outcome Orientation. How much the organization emphasizes on achieving goals (results), rather than on how to achieve the goals (processes). 4) People Orientation. How far the organization is willing to consider the human factor (employees) in making management decisions. 5) Team Orientation. How much the organization emphasizes group work (team), rather than individual work, in completing tasks. 6) Aggressiveness. How much the organization encourages its employees to compete with each other, rather than cooperate with each other. 7) Stability. How much the organization emphasizes on maintaining the status quo in making various decisions and actions. 


\subsubsection{Information Asymmetry}

Information asymmetry according to Scott [14] "Information asymmetry is of such importance to accounting theory is that securities market is subject to information asymmetry problem. Even if security market prices fully reflect all publicly available information". Information asymmetry is a situation where there is a misalignment of information between a party who owns or provides information and a party who needs information [7]. There are two types of information asymmetry as stated by Scott [14] namely: 1 Adverse selection, occurs because some people such as company managers and other insiders are more aware of the present conditions and future prospects of the company than outside investors. 2 Moral Hazard, can occur because of the separation of ownership and control.

\subsubsection{Framework}

Organizational Culture is a norm or value that is believed to guide behavior for members or employees in the organization. Organizational culture contributes significantly to the formation of behavior, because it is organizational culture that guides the actions of employees or members. So it can be assumed that a bad organizational culture will influence employees in committing fraud. In the research of Indriani [6] shows that organizational culture influences the tendency of accounting fraud. Information asymmetry is a condition in which there is an imbalance in information acquisition between the agent as the information provider and the principal as the user of the information. If there is an information gap in an organization, it can open up opportunities for fund managers to commit fraud. Research conducted by Wilopo [7] results that information asymmetry has a significant positive effect on the tendency of accounting fraud.

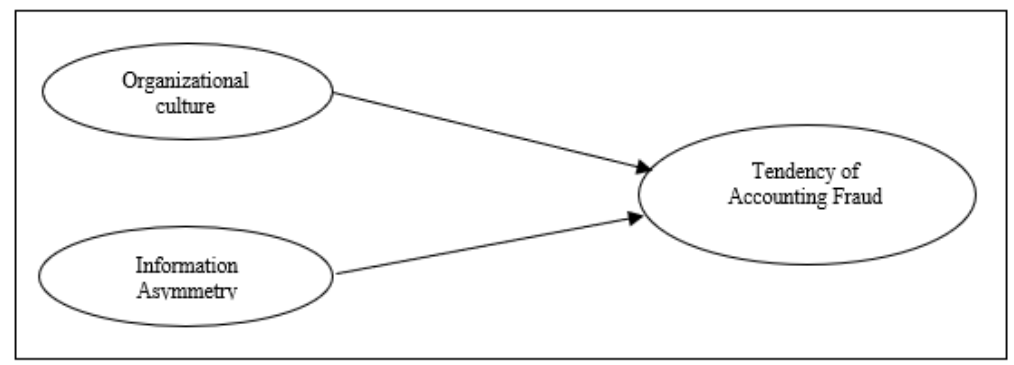

Fig 1. Framework

\section{Hypothesis}

Based on the above framework, the hypothesis is as follows:

H1: $\quad$ Organizational culture has a significant effect on accounting fraud

H2: Information asymmetry has a significant effect on accounting fraud

\section{Research Method}

This study is a causal quantitative research that aims to test hypotheses on the affect of organizational culture (X1) and information asymmetry (X2) as independent variables on the tendency of accounting fraud (Y) as the dependent variable. Data sources used in this study are primary data, which are data that were obtained directly from respondents. Data collection method used in this study is the questionnaire method. In this study the data analysis used was the Partial Least Square (PLS) approach. The population in this research were all SKPDs in 
South Tangerang and Tangerang with a total of 79 SKPDs and as many as 41 SKPDs there of were used as research samples. The selection of research samples is determined based on the purposive sampling method. Respondents used in this study were employees of the finance department. Organizational culture variable consists of 7 dimensions namely, 1) Innovation and risk taking, 2) Attention to detail, 3) Outcome orientation, 4) Individual orientation, 5) Team orientation, 6) Aggressiveness and 7) Stability. The information asymmetry variable consists of 2 dimensions, 1) Adverse selection and 2) Moral hazard. The tendency of accounting fraud variable consists of 3 dimensions, namely, 1) Asset Misappropriation, 2) Fraudulent Statement and 3) Corruption.

\section{Results and Discussion}

\subsection{Description of Research Variables}

The results of the descriptive analysis of each variable are as follows:

Table 1. Variable Description

\begin{tabular}{l|l|l}
\hline No & Variable & Average value \\
\hline 1 & Tendency of Accounting Fraud & 2,73 \\
\hline 2 & Organizational Culture & 4,02 \\
\hline 3 & Information Asymmetry & 3,25 \\
\hline
\end{tabular}

Statistical results of variable description indicate that the organizational culture variable has an average value of 4,02. This means that the organizational culture in SKPD of Tangerang and South Tangerang are good. The information asymmetry variable has an average value of 3,25. This means that SKPD of Tangerang and South Tangerang provide information asymmetry which is not large. And the tendency of accounting fraud variable has an average value of 2,73 . This means that the tendency for accounting fraud is low in SKPD of Tangerang and South Tangerang.

\subsection{Validity and Reliability Test}

The following are the results of the output loading factor from the construct of Organizational Culture, Information Asymmetry and Tendency of Accounting Fraud on Smart PLS applications:

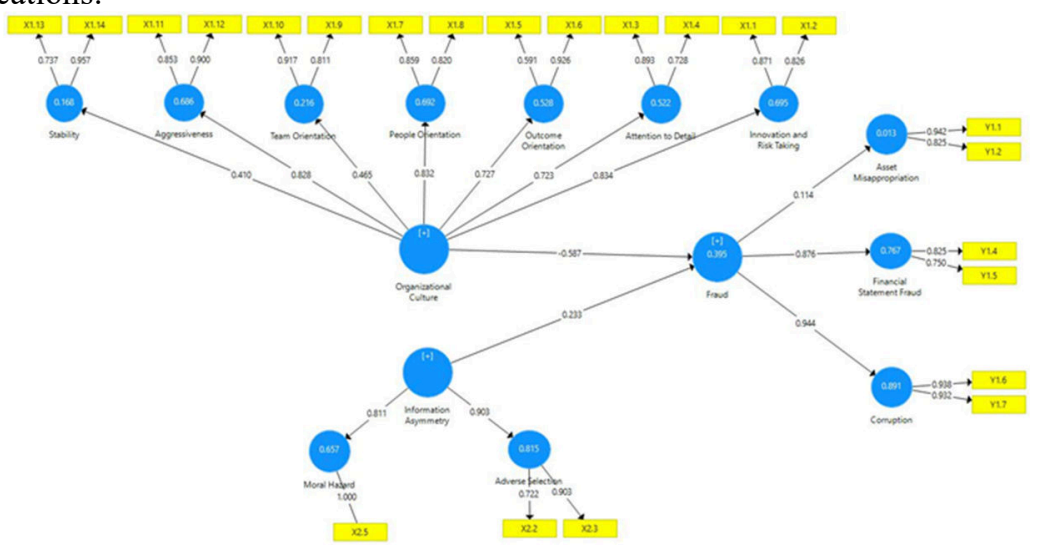

Fig 2 Output Loading Factor of Study 
Based on the output in the path diagram above, the loading factor for each construct fulfills convergent validity, which is the indicator value $>0.5$. All loading factors are using significance level of $5 \%$. In a research, a variable is determined to be quite reliable if the variable has a construct reliability value greater than 0,6 . Based on the above output reliability results, it can be concluded that for all dimensions in organizational culture, information asymmetry and tendency of accounting fraud have composite reliability above 0,7 and Cronbach's alpha above 0,6 yet attention to details, individual orientation, outcome orientation, fraudulent statement and adverse selection are below 0,6 but still considered submarginal by looking at the value of composite reliability above 0,7 , so it can be concluded that the indicators used in each dimension have good reliability or are able to measure the construct.

\subsection{Structural Evaluation of Goodness of Fit Model (Inner Model)}

Evaluation of goodness of fit model of the research is measured using the value of RSquare (R2). The R-Square (R2) value in PLS output is 0,395 and the Adjusted R-Square (Adj-R2) value is 0,362. This means that the tendency of accounting fraud model is affected by the organizational culture, the effectiveness of internal control systems and the information asymmetry of $39,5 \%$, the rest is affected by other variables outside the research model.

\subsection{Hypothesis Testing}

Hypothesis test in this study is based on the results of the output of Partial Least Square and using a significant level of 5\%. Parameter coefficient value and Tstatistic significance level can be seen in table 2 as follows:

Table 2 Hypothesis Testing Results

\begin{tabular}{c|c|c|c|c}
\hline Variables Effect & $\begin{array}{c}\text { Parameter } \\
\text { coefficient }\end{array}$ & T $_{\text {statistic }}$ & P Value & Note \\
\hline $\begin{array}{c}\text { Organizational Culture -> } \\
\text { Tendency of Accounting } \\
\text { Fraud }\end{array}$ & $-0,587$ & 5,140 & 0,000 & Significant* \\
\hline $\begin{array}{c}\text { Information asymmetry -> } \\
\text { Tendency of Accounting } \\
\text { Fraud }\end{array}$ & 0,233 & 1,745 & 0,082 & Not Significant \\
\hline
\end{tabular}

Note: *Significance level of $5 \%$

Based on the results of the first hypothesis test, organizational culture variables have a significant effect on accounting fraud with a Pvalue of 0,000 less than the significant level of 0.05 and a statistical value of 5.140> ttable 1.96, so that the first hypothesis in the study is accepted. The second hypothesis test results, the information asymmetry variable does not have a significant effect on accounting fraud with a Pvalue of more than a significant level $(0.05)$ of 0.082 and a statistical value of $1.745<$ ttable 1.96 , so that the second hypothesis in the study is rejected.

\subsection{Discussion}

Based on the results of statistical tests and significance test, the organizational culture had a significant effect on the tendency of accounting fraud. Yuliana [15] in their research stated that organization that already has a habit of organizing a good, solid and consistent culture, it will certainly do any work that is assigned to it well. According Kinichi et al in Setyaningsih 
[16] organizational culture as a set of assumptions from a group that determine how to perceive, think and react to various environments which include three characteristics, namely organizational culture that is passed on to employees through a characteristic process, organizational culture affects employee behavior in the workplace and organizational culture will be different for each level. If the majority of employees have the same opinion about the mission and values of the organization, then the culture is strong [17]. A strong organizational culture can increase employees' sense of belonging to the company and minimize the acts of fraud that might occur.

Based on the answers of respondents in this study, the institution stressed its employees to be aggressive, not relaxed, able to work with teams and to be more innovative, it described that the organizational culture in SKPD creates a positive or good atmosphere. The results of this study are in line with a study conducted by Indriani [6] and Surjandari et al., [18] that organizational culture had an effect on the tendency of accounting fraud, while Kiswanto et al., [5] showed that ethical culture of an organization had no effect on the tendency of accounting fraud.

Based on the results of statistical tests and significance test, the information asymmetry had no significant effect on the tendency of accounting fraud. Information asymmetry had no significant effect on the tendency of accounting fraud due to the low information gap between agents and principals which can be seen from the responses of respondents who stated that all activities carried out by agents are known by principals. This shows that the institution is transparent regarding any matters related to the institution operations that can affect the financial statements, so it will reduce information asymmetry and will minimize the opportunity for accounting fraud. In SKPD, information asymmetry can be overcome by monitoring or supervision conducted by regional Inspectorate and audits conducted by BPK. The results of this study are in line with studies conducted by Widhiastuti et al., [8] and Nurlaeliyah [19] which resulted that information asymmetry had no effect on the tendency of accounting fraud. But the results of this study contradict the study conducted by Wilopo [7] and Indrijawati [20] which showed a positive effect between information asymmetry and the tendency of accounting fraud.

\section{Conclusions}

Based on the results of the research and discussion presented above, it can be concluded that the information asymmetry does not significantly effect on the tendency of accounting fraud. While organizational culture has a significant effect on tendency of accounting fraud. This implies that agencies should continue to improve the existing organizational culture in order to form good behavior or habits in employees and so that the agency's goals can be achieved. In addition, the tendency of accounting fraud that may occur can be minimized. Variable information asymmetry still results in inconsistencies in the results of research with theory and previous research. For this reason, it is hoped that researchers will be able to develop new dimensions and indicators that can be more accurate.

\section{References}

[1] P. A. A. Putri and S. A. Irwandi, "The determinants of accounting fraud tendency," Indones. Account. Rev., 2017. 
[2] A. Fachrunisa, A., Safitri, D., \& Hasan, "Pengaruh keefektifan pengendalian internal, keadilan distributif, keadilan prosedural, dan budaya etis organisasi terhadap kecenderungan kecurangan (fraud) akuntansi," Jom FEKON, 2015.

[3] K. Saddhono, "Cultural and social change of foreign students in Indonesia: The influence of Javanese Culture in Teaching Indonesian to Speakers of Other Languages (TISOL) Open Access," IOP Conf. Ser. Earth Environ. Sci., vol. 126, no. 1, 2018.

[4] K. Saddhono, "Integrating culture in Indonesian language learning for foreign speakers at Indonesian universities," J. Lang. Lit., vol. 6, no. 2, pp. 273-276, 2015.

[5] Kiswanto, F. Mustikawati, D. Puspitasari, H. Murtini, and D. I. Gunawan, "Perception of Village Financial Managers of Accounting Fraud Tendency ( Empirical Study In Grobogan District )," Int. Conf. Stud. Business, Manag. Educ. Law Manila, 2017.

[6] N. Indriani, "The Effect of Effectiveness of Internal Control System, Leadership Style, Conformity Compensation, Culture and Ethical Organization, Organizational Commitment and Law Enforcement on Fraud in Regional Level Work Units of Pidie Jaya," Acc. Financ. Manag. J., 2018

[7] Wilopo, “Analisis Faktor-faktor yang Berpengaruh Terhadap Kecenderungan Kecurangan Akuntansi: Studi pada Perusahaan Publik dan Badan Usaha Milik Negara di Indonesia," J. Ris. dan Akunt. Indones., 2006.

[8] R. Widhiastuti, T. H. Utaminingtyas, and I. Wahyuningsih, "Determinants of fraud tendency in the management of village funds," J. Adv. Res. Law Econ., 2020.

[9] D. E. Weygandt, J. J., Kimmel, P. D., \& Kieso, Accounting Principles 12th Edition. USA: John Wiley \& Sons., 2015.

[10] A. Arens, E. Randal, and M. S. Beasley, Auditing and Assurance Services : An integrated Approach. 2012.

[11] Y. D. Purnomo, "Analysis of Factors Affecting The Tendency of Accounting Fraud with The Mediation of Ethical Behavior," Account. Anal. J., vol. 6, no. 2, pp. 299-312, 2017.

[12] M. Robins, S. P., \& Coulter, Management. United States: Pearson Education Limited, 2016.

[13] W. Zheng, B. Yang, and G. N. McLean, "Linking organizational culture, structure, strategy, and organizational effectiveness: Mediating role of knowledge management," J. Bus. Res., 2010.

[14] W. R. Scott, Financial Accounting Theory 7th Edition. 2015.

[15] Yuliana and H. Setiyawati, "The Influence of Organizational Culture and Organizational Commitment on the Quality of Accounting Information and Impact on Financial Accountability ( Survey in Private Company at the Regency of Tanah Bumbu South Kalimantan )," Sch. Bull., vol. 5(8), pp. 406-413, 2019.

[16] P. R. Setyaningsih and N. Nengzih, "Internal control, organizational culture, and quality of information accounting to prevent fraud: Case study from Indonesia's agriculture industry," Int. J. Financ. Res., 2020.

[17] S. P. Robbins and T. A. Judge, Organizational Behavior 15th Edition. 2013.

[18] I. Surjandari, D. A., \& Martaningtyas, "An Empirical Study: The Effect of Performance Incentives, Internal Control System, Organizational Culture, on Fraud of Indonesia Government Officer," Mediterr. J. Soc. Sci., 2015.

[19] S. Nurlaeliyah, "Analysis of Factors Affecting The Tendency of Accounting Fraud with An Ethical Behavior As Intervening Variable," Account. Anal. J., 2017.

[20] A. Indrijawati, N. Nichen, and K. Kartini, "THE TENDENCY OF ACCOUNTING FRAUD IN MEDIATION INFLUENCE OF INTERNAL CONTROL AND INFORMATION ASYMMETRY ON ORGANIZATIONAL ACCOUNTABILITY," Mega Akt. J. Ekon. dan Manaj., 2019. 